\title{
Effects of Hyperaccumulator Straw on Soil Nutrient Availability and Soil Enzyme Activity of Cyphomandra betacea under Cadmium Stress
}

\author{
Jing $\mathrm{He}^{1, \mathrm{a}}$, Qianqian Ma ${ }^{1, \mathrm{~b}}$, Lijin Lin ${ }^{2, \mathrm{c}}$, and Ming'an Liao ${ }^{2, \mathrm{~d}^{*}}$ \\ ${ }^{1}$ College of Horticulture, Sichuan Agricultural University, Chengdu, Sichuan, China \\ ${ }^{2}$ Institute of Pomology and Olericulture, Sichuan Agricultural University, Chengdu, Sichuan, China \\ a372710146@qq.com, b2282583901@qq.com, 'llj800924@163.com, Iman@sicau.edu.cn
}

${ }^{*}$ Corresponding author

\section{Keywords: Hyperaccumulator straw; Cyphomandra betacea; Soil nutrient; Soil enzyme}

Abstract: A pot experiment was conducted to study the effects of hyperaccumulator straw on soil nutrient availability and soil enzyme activities of Cyphomandra beracea under Cadmium (Cd) stress. Four Cd-hyperaccumulator species (Solanum photeinocarpum, Tagetes erecta, Galinsoga parviflora, Bidens pilosa) straws were applied as mulches on the $\mathrm{Cd}$-contaminated soil surface which planted $C$. beracea. The results showed that mulching hyperaccumulator straw on soil surface increased soil organic matter content, and soil available contents of $\mathrm{N}, \mathrm{P}$ and $\mathrm{K}$. The contents of organic matter content and available $\mathrm{N}$ were ranked as: T. erecta $>$ S. photeinocarpum $>$ G. parviflora $>$ B. pilosa $>$ control, and the available $\mathrm{P}$ and $\mathrm{K}$ contents were ranked as: $S$. photeinocarpum $>$ T. erecta $>$ G. parviflora $>$ B. pilosa $>$ control. The straws of $S$. photeinocarpum and $T$. erecta increased the soil catalase, polyphenol oxidase, urease and sucrase activities, but the straws of $G$. parviflora and B. pilosa reduced them. Therefore, mulching with the straws of $S$. photeinocarpum and $T$. erecta could promote growth of $C$. betacea under $\mathrm{Cd}$ stress.

\section{Introduction}

Heavy metal contaminated soil causes huge losses in the yield of economic crop, and would even get into the food chain [1]. Cadmium $(\mathrm{Cd})$ is one of heavy metal that is not biodegradable and considered to be a very hazardous element to environment [2]. Mulching with plant straw on soil surface is one of the natural methods using in agricultural production, and straw mulch decomposes in the soil and converts into organic matter, allelopathic substances and other nutrients, which can fertilize the soil, improve soil texture and affect physiological and biochemical activities of soil microorganisms [3-4]. If we apply the plant straw in heavy metal contaminated soil, the plant straw could affect the heavy metal bioavailability, and decrease or increase the heavy metal absorption of living plant [5]. Cyphomandra betacea is a commercially attractive fruit, which distributes in New Zealand, Sri Lanka, and Southwest of China [6]. In this study, to study effects of hyperaccumulator straw on soil nutrient availability and soil enzyme activity of $C$. betacea under Cd stress, we planted $C$. betacea seedlings in Cd-contaminated soil, and mulching with straws of four Cd-hyperaccumulator species (Solanum photeinocarpum [7], Tagetes erecta [8], Galinsoga parviflora [9] and Bidens pilosa [10] on soil surface. The aim of the study was to screen hyperaccumulator straw which could enhance soil nutrient availability and soil enzyme activity of $C$. betacea under $\mathrm{Cd}$ stress, and provide a reference for other fruit trees.

\section{Materials and Method}

Materials. The inceptisol soil samples were collected from Ya'an campus farm of the Sichuan Agricultural University $\left(29^{\circ} 59^{\prime} \mathrm{N}, 102^{\circ} 59^{\prime} \mathrm{E}\right)$, China, in July 2014 . The basic properties of the soil were the same as reference [9]. The shoots of $S$. photeinocarpum, T. erecta, G. parviflora and B. pilosa were collected from the Ya'an campus farm (from uncontaminated soil) in July 2014 . The shoots were dried at $80^{\circ} \mathrm{C}$ to constant weight, then finely ground and sieved through a 5-mm-mesh nylon sieve. 
Experimental Design. The experiment was conducted at the Ya'an campus farm from July to October in 2014. The soil samples were air-dried and passed through a 5-mm sieve. Three kilograms of the air-dried soil was weighed into each polyethylene pot $(15 \mathrm{~cm}$ high, $18 \mathrm{~cm}$ in diameter). $\mathrm{Cd}$ was added to soils as $\mathrm{CdCl}_{2} \cdot 2.5 \mathrm{H}_{2} \mathrm{O}$ at $10 \mathrm{mg} / \mathrm{kg}$. The soils were mixed immediately and again after 4 weeks, during which soil moisture was kept at $80 \%$. Three uniform seedlings with five euphyllas of $C$. betacea were transplanted into each pot, and $6 \mathrm{~g}$ shoots of four Cd-hyperaccumulator species were applied as mulches on the soil surface in each pot (equivalent to $225 \mathrm{~g} / \mathrm{m}$ ). Five treatments were applied: not mulched with straw (control), mulched with $S$. photeinocarpum straw, mulched with $T$. erecta straw, mulched with G. parviflora straw, and mulched with $B$. pilos $a$ straw. Each treatment was repeated three times with a completely randomized design with $10-\mathrm{cm}$ spacing between pots. The soil moisture was maintained at $80 \%$ of field capacity from when the C. betacea seedlings were transplanted until the plants were harvested.

Sample Analysis. 40 days later, the plants were gently removed from the soil. The soil samples were collected, and dried naturally and ground into powder (granule diameter $<0.149 \mathrm{~mm}$ and $1 \mathrm{~mm}$ ) to determine the organic carbon content, available nitrogen $(\mathrm{N})$, available phosphorus $(\mathrm{P})$, available potassium $(\mathrm{K})$ [11] and soil enzyme (catalase, polyphenol oxidase, urease and sucrase) activity [12].

Statistical Analyses. Statistical analyses were performed using SPSS 13.0 statistical software (IBM, Chicago, IL, USA). Data were analyzed by one-way analysis of variance with least significant difference at a $5 \%$ confidence level.

\section{Results and Discussion}

Soil Nutrient Availability. When mulching hyperaccumulator straw on Cd-contaminated soil surface, the organic matter content increased compared with control, and was ranked as: T. erecta $>S$. photeinocarpum $>$ G. parviflora $>$ B. pilosa $>$ control (Table 1), which was related to the decomposition matter of straw. The available $\mathrm{N}$ content was ranked as: T. erecta $>S$. photeinocarpum $>$ G. parviflora $>$ B. pilosa > control, and the treatments of S. photeinocarpum, T. erecta, G. parviflora and B. pilosa increased available $\mathrm{N}$ content by $22.01 \%(p<0.05), 22.44 \%(p<0.05), 19.24 \%(p<0.05)$ and $5.52 \%$ $(p>0.05)$ respectively compared with control. The available $\mathrm{P}$ and $\mathrm{K}$ contents were ranked as: $S$. photeinocarpum $>$ T. erecta $>$ G. parviflora $>$ B. pilosa $>$ control. The treatments of $S$. photeinocarpum, T. erecta, G. parviflora and B. pilosa increased available P content by $92.72 \%(p<0.05), 70.61 \%(p<$ $0.05), 39.18 \%(p<0.05)$ and $5.56 \%(p>0.05)$ respectively compared with control, and the treatments of S. photeinocarpum, T. erecta, G. parviflora and B. pilosa increased available K content by $32.83 \%$ ( $p<$ $0.05), 30.15 \%(p<0.05), 26.16 \%(p<0.05)$ and $13.87 \%(p<0.05)$ respectively compared with control. So, mulching with the straws of $S$. photeinocarpum, T. erecta, G. parviflora and B. pilosa increased available nutrients of $\mathrm{Cd}$-contaminated soil, which was benefit for $C$. betacea seedlings growth, and was consistent with other studies [13].

Table 1 Soil nutrient availability content

\begin{tabular}{|l|c|c|c|c|}
\hline \multicolumn{1}{|c|}{ Treatments } & $\begin{array}{c}\text { Organic matter } \\
(\mathrm{mg} / \mathrm{g})\end{array}$ & $\begin{array}{c}\text { Available N } \\
(\mathrm{mg} / \mathrm{kg})\end{array}$ & $\begin{array}{c}\text { Available P } \\
(\mathrm{mg} / \mathrm{kg})\end{array}$ & $\begin{array}{c}\text { Available K } \\
(\mathrm{mg} / \mathrm{kg})\end{array}$ \\
\hline Control & $23.11 \pm 0.52 \mathrm{~b}$ & $37.16 \pm 0.45 \mathrm{~b}$ & $21.03 \pm 0.39 \mathrm{~d}$ & $102.50 \pm 1.04 \mathrm{~d}$ \\
\hline S. photeinocarpum & $25.56 \pm 0.58 \mathrm{a}$ & $45.34 \pm 0.63 \mathrm{a}$ & $40.53 \pm 0.04 \mathrm{a}$ & $136.15 \pm 1.71 \mathrm{a}$ \\
\hline T. erecta & $25.60 \pm 0.63 \mathrm{a}$ & $45.50 \pm 0.73 \mathrm{a}$ & $35.88 \pm 0.11 \mathrm{~b}$ & $133.40 \pm 1.92 \mathrm{ab}$ \\
\hline G. parviflora & $25.00 \pm 0.59 \mathrm{ab}$ & $44.31 \pm 0.48 \mathrm{a}$ & $29.27 \pm 0.91 \mathrm{c}$ & $129.31 \pm 1.78 \mathrm{~b}$ \\
\hline B. pilosa & $24.21 \pm 0.69 \mathrm{ab}$ & $39.21 \pm 1.18 \mathrm{~b}$ & $22.20 \pm 0.58 \mathrm{~d}$ & $116.72 \pm 0.50 \mathrm{c}$ \\
\hline
\end{tabular}

Soil Catalase and Polyphenol Oxidase Activities. When mulching hyperaccumulator straw on Cd-contaminated soil surface, the straws of $S$. photeinocarpum and T. erecta increased the soil catalase and polyphenol oxidase activities, but the straws of G. parviflora and B. pilosa reduced them (Fig. 1 A, B), 
which was related to the allelopathic substances from the different species straws [14-15]. The soil catalase and polyphenol oxidase activities were ranked as: $T$. erecta $>S$. photeinocarpum $>$ control $>G$. parviflora $>$ B. pilosa, and the T. erecta straw increased soil catalase and polyphenol oxidase activities by $100.00 \%(p<0.05)$ and $81.25 \%(p<0.05)$, respectively.
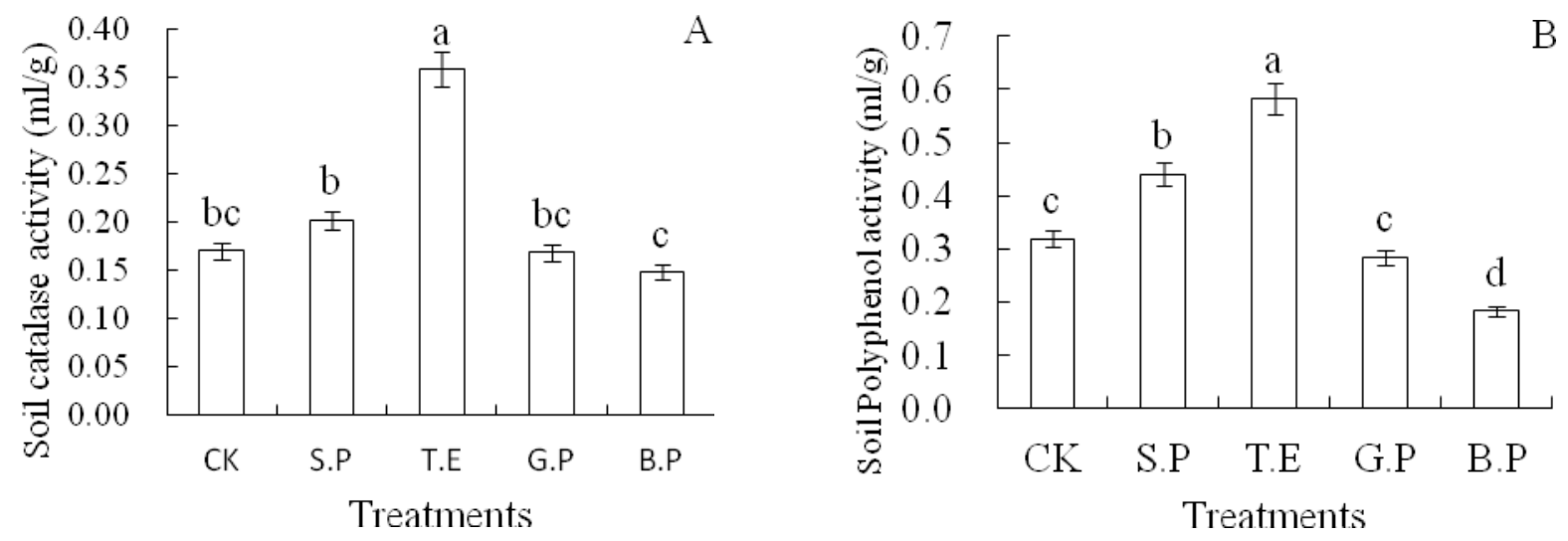

Fig. 1 Effects of hyperaccumulator straws mulching on soil catalase activity and soil polyphenol oxidase activity. $\mathrm{A}=$ Soil catalase activity, $\mathrm{B}=$ Soil polyphenol oxidase activity. $\mathrm{CK}=$ not mulched with straw (control), S.P = mulched with $S$. Photeinocarpum straw, T.E = mulched with $T$. erecta straw, G.P = mulched with $G$. parviflora straw, B.P = mulched with B. pilosa straw.

Soil Urease and Sucrase Activities. The same as soil catalase and polyphenol oxidase activities, when mulching hyperaccumulator straw on Cd-contaminated soil surface, the straws of S. photeinocarpum and $T$. erecta increased the soil urease and sucrase activities, but the straws of $G$. parviflora and B. pilosa reduced them (Fig. 2 A, B), which was also related to the allelopathic substances from the different species straws [14-15]. The soil urease and sucrase activities were ranked as: . erecta $>S$. photeinocarpum $>$ control $>$ G. parviflora $>$ B. pilosa, and the T. erecta straw increased soil urease and sucrase activities by $24.19 \%(p$ $<0.05)$ and $15.70 \%(p<0.05)$, respectively. Therefore, the straws of S. photeinocarpum and T. erecta could use to enhance soil enzyme activity under $\mathrm{Cd}$ stress of $C$. betacea, and the T. erecta straw was the best.
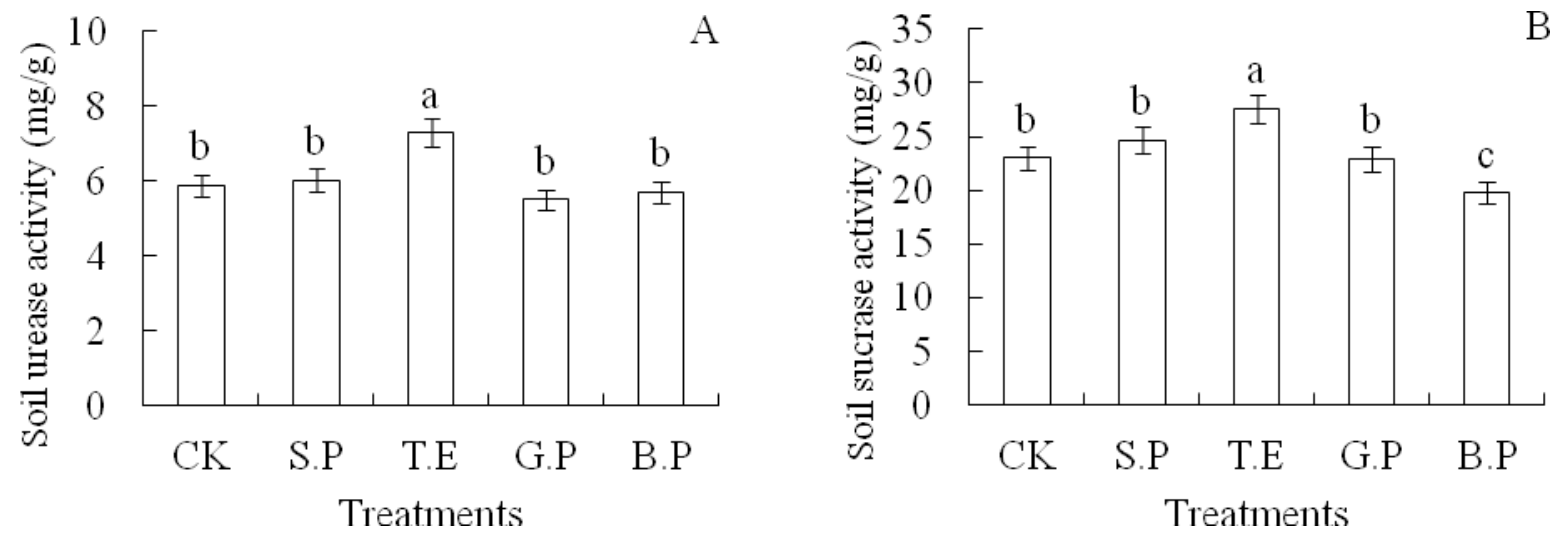

Fig. 2 Effects of hyperaccumulator straws mulching on soil urease and sucrase activities. A = Soil urease activity, B $=$ Soil sucrase activity. $\mathrm{CK}=$ not mulched with straw (control), S.P = mulched with $S$. Photeinocarpum straw, T.E = mulched with T. erecta straw, G.P = mulched with G. parviflora straw, B.P $=$ mulched with $B$. pilosa straw. 


\section{Conclusions}

Mulching hyperaccumulator straw on Cd-contaminated soil surface of $C$. betacea increased organic matter content, available $\mathrm{N}$ content, available $\mathrm{P}$ content and available $\mathrm{K}$ content of soil. The organic matter content and available N content were ranked as: T. erecta $>S$. photeinocarpum $>$. parviflora $>$ B. pilosa $>$ control, and the available $\mathrm{P}$ and $\mathrm{K}$ contents were ranked as: $S$. photeinocarpum $>T$. erecta $>G$. parviflora $>$ B. pilosa $>$ control. Mulching hyperaccumulator straw on Cd-contaminated soil surface, the straws of $S$. photeinocarpum and $T$. erecta increased the soil catalase, polyphenol oxidase, urease and sucrase activities, but the straws of $G$. parviflora and B. pilosa reduced them. Therefore, mulching with the straws of $S$. photeinocarpum and $T$. erecta could promote growth of $C$. betacea under Cd stress.

\section{References}

[1] M. Arora, B. Kiran, S. Rani, A. Rani, B. Kaur, N Mittal, Heavy metal accumulation in vegetables irrigated with water from different sources, Food Chemistry 11 (2008) 811-815.

[2] R.H. Kretsinger, V.N. Uversky, E.A. Permyakov, Encyclopedia of Metalloproteins, Springer, 2013.

[3] B. Gong, S. Bloszies, X. Li, M. Wei, F.J. Yang, Q.H. Shi, X.F. Wang, Efficacy of garlic straw application against root-knot nematodes on tomato, Scientia Horticulturae 161 (2013) 49-57.

[4] H.H. Zhu, J.S. Wu, D.Y. Huang, Q.H. Zhou, S.L. Liu, Y.R. Su, W.X. Wei, J.K. Syers, Y. Li, Improving fertility and productivity of a highly-weathered upland soil in subtropical China by incorporating rice straw, Plant and Soil 331 (2010) 427-437.

[5] L.J. Lin, M.A. Liao, Y.J. Ren, L. Luo, X. Zhang, D.Y. Yang, J. He, Effects of mulching tolerant plant straw on soil surface on growth and cadmium accumulation of Galinsoga parviflora, PloS ONE 9 (2014) e114957.

[6] T. Stangeland, S.F. Remberg, K.A. Lye, Total antioxidant activity in 35 Ugandan fruits and vegetables. Food Chemistry 113 (2009) 85-91.

[7] X.F. Zhang, H.P. Xia, Z.A. Li , P. Zhuang, B. Gao, Identification of a new potential Cd-hyperaccumulator Solanum photeinocarpum by soil seed bank-metal concentration gradient method, Journal of Hazardous Materials 189 (2011) 414-419.

[8] N. Rungruang, S. Babel, P. Parkpian, Screening of potential hyperaccumulator for cadmium from contaminated soil, Desalination \& Water Treatment 32 (2011) 19-26.

[9] L.J. Lin, Q. Jin, Y.J. Liu, B. Ning, M.A. Liao, L. Luo, Screening of a new cadmium hyperaccumulator, Galinsoga parviflora, from winter farmland weeds using the artificially high soil cadmium concentration method, Environmental Toxicology and Chemistry 33 (2014) 2422-2428.

[10] Y. Sun, Q. Zhou, L. Wang, W. Liu, Cadmium tolerance and accumulation characteristics of Bidens pilosa L. as a potential Cd-hyperaccumulator, Journal of Hazardous Materials 161 (2009) 808-814.

[11] S.D. Bao, Soil Agrochemical Analysis, China Agriculture Press, Beijing, China, 2000 (In Chinese).

[12] Y.S. Guan, Soil Enzyme and Study Method, China Agriculture Press, Beijing, China, 1986 (In Chinese).

[13] A. Whitbread, G. Blair, Y. Konboon, R. Lefroy, K. Naklang, Managing crop residues, fertilizers and leaf litters to improve soil $\mathrm{C}$, nutrient balances, and the grain yield of rice and wheat cropping systems in Thailand and Australia, Agriculture, Ecosystems \& Environment 100 (2003) 251-263.

[14] R.G. Burns, Enzyme activity in soil: location and a possible role in microbial ecology, Soil Biology and Biochemistry 14 (1982) 423-427.

[15] Y. Gu, P. Wang, C.H. Kong, Urease, invertase, dehydrogenase and polyphenoloxidase activities in paddy soil influenced by allelopathic rice variety, European Journal of Soil Biology 45 (2009) 436-441. 